\title{
COMMENT
}

\section{STATE RECIPROCITY STATUTES AND THE INHERITANCE RIGHTS OF NONRESIDENT ALIENS}

\begin{abstract}
$\mathrm{I}_{\mathrm{N}}$ recent decades a number of states have adopted statutes under which the inheritance rights of nonresident aliens are made to depend upon a corresponding right of United States citizens to inherit property from the country of which the nonresident alien is a citizen or subject. ${ }^{1}$ The growing body of case law which has resulted from these statutes indicates not only that they fail effectively to accomplish their ostensible purposes, but also that they produce undesirable results. The increasing prevalence of the benighted
\end{abstract}

\footnotetext{
${ }^{1}$ Since reciprocity statutes regulate testamentary disposition as well as intestate succession, the word "inherit" is herein used in its popular sense, as the equivalent of to take or receive. BLAck, LAw Dictionary 992 (4th ed. 1951).

The most widely-used formulation of the reciprocity statute is the 1947 California version, subsequently copied by North Carolina and Iowa and slightly modified in California. The wording is as follows:

"The rigbt of aliens not residing within the United States or its territories to take real property in this State by succession or testamentary disposition, upon the the same terms and conditions as residents and citizens of the United States is dependent in each case upon the existence of a reciprocal right upon the part of citizens of the United States to take real property upon the same terms and conditions as residents and citizens of the respective countries of which such aliens are residents and the right of aliens not residing in the United States or its territories to take personal property in this State by succession or testamentary dispositiou, upon the same terms and conditions as residents and citizens of the United States is dependent in each case upon the existence of a reciprocal right upon the part of citizens of the United States to take personal property upon the same terms and conditions as residents and citizens of the respective countries of which such aliens are residents.

"The burden shall be upon such nonresident aliens to establish the fact of existence of the reciprocal rights set forth in [the foregoing section]. . . .

"If such reciprocal rights are not found to exist and if no heirs other than such aliens are found eligible to take such property, the property shall be disposed of as escheated property." CAL. Prob. Code $\$ \S 259-259.2$; IOWA Code $\$ 567.8$ (Supp. 1962); N.C. GeN. Stat. $\$ \S 64-3$ to -5 (1960).

The California statute was slightly amended in 1957 to allow judicial notice of the foreign law, but the amendment bas had little or no effect on the way the statute is administered. See In re Feierman's Estate, 20 Cal. Rptr. 883, 202 A.C. 610 (1962).

Other states which have adopted reciprocity statutes are Arizona, Connecticut, Montana, Nevada, Oklahoma, Oregon and Texas. ARIz. REv. STAt. ANN. \$14-212 (c) (1956); Conn. Gen. Stat. Rev. \$47-57 (1958); Mont. Rev. Codes AnN. \$§ 91-520 and .521 (Supp. 1961); Nev. Rev. Stat. $\$ \$ 134.230-.250$ (1957); OrLA. Srat. tit. 60, §121 (1951); OrE. Rev. Stat. \$111.070 (1961); Tex. Rev. Crv. Stat. art. 167 (4) (1959).
} 
reciprocity statute indicates the need for re-examination of the ageold problem of inheritance by nonresident aliens.

\section{The Inherttance Rights of Aliens in General}

At common law the ability of resident and nonresident aliens to inherit was subject to certain limitations. While they could freely inherit personal property, ${ }^{2}$ the law did not permit them to acquire real property by operation of law, as by succession, ${ }^{3}$ and further specified that land interests acquired by purchase or descent were subject to forfeiture to the state through a proceeding initiated by the sovereign. 4 The development of these restrictions in medieval England can be attributed to the importance of estates in land, the strong allegiance required by kings of their landholders, and a continuing fear of foreign influence. ${ }^{8}$

In the United States, where immigration has contributed to economic development, the past two hundred years has seen a general enhancement of the property rights of aliens. Although some restrictions remain, many of the common law land disabilities of aliens have been removed by state constitutions and statutes, ${ }^{6}$ and by federal treaties. ${ }^{7}$

\footnotetext{
Fourdrin v. Gowdey, 3 Myl. \& K. 389, 40 Eng. Rep. 146 (Ch. 1834); 1 BLAckstone, COMMENTARIES $\$ 872$.

${ }^{3}$ Calvin's Case, 7 Coke 1a, at 25a, 77 Eng. Rep. 377, at 407 (1606); 6 Powerl, Real Property I 1002 (1958).

4 See Governeur's Heirs v. Robertson, 24 U.S. (11 Wheat.) 332, 355.56 (1826); 5 TIFFANY, Real Property $\$ 1377$ (3d ed. 1939).

- See 1 Blackstone, Commentaries 372.

- The land disabilities of aliens have been fully removed in at least sixteen states. 1 Powell, Real Property I 102 (1949, Supp. 1962). Five states have removed the disabilities of "alien friends." Id. I 103. Eight states, the Territories, and the Disstrict of Columbia have done the same for resident aliens. Id. I 104. Ten states impose partial disabilities which are affected by such factors as (1) the method by which the alien acquires his interest, (2) the period of time the alien is permitted to retain land interests, (8) whether the ahen intends to become a citizen, (4) the quantity of land in question, (5) whether the land is located in an urban or agricultural area, (6) whether the alien resides in the state, and (7) the use to which the land is to be devoted. Id. I 105. A number of states have imposed disabilities on aliens not eligible for citizenship. See Comment, 56 YaLE L.J. 1017, 1019-20 (1947). The Supreme Court has struck down some of these laws, and others are of doubtful constitutional validity. 1 Poweld, Real Property TI 102, 106 (1949, Supp. 1962).

7 Through a number of commercial treaties the United States has guaranteed some inheritance rights to citizens of foreign countries. Most of these treaties, patterned on the 1923 treaty between the United States and Germany, provide for national treatment as to inheritance taxes and, in case aliens are ineligible under local law to inherit real property, for national treatment as to withdrawal of proceeds from
} 
Running counter to this liberal trend is the comparatively recent legislation enacted in some states to stop the flow of inheritances to countries hostile to the United States. These recent provisions generally require either that there be a reciprocal right of inheritance or that the foreign beneficiary be able freely to receive and use his inheritance in his home country. ${ }^{8}$ Both these requirements go beyond the common law and older statutory limitations in that they are applied not only to real property, but also to personalty. ${ }^{\circ}$ Reciprocity is by far the more severe of the two recent types of restrictions since it typically involves escheat of the property to the state. Broad in scope and severe in effect, reciprocity statutes quite naturally draw a critical eye.

\section{II}

\section{The Purposes and Effectiveness of Reciprocity Statutes}

Reciprocity statutes are designed to accomplish two primary goals: First, to keep money and property out of the hands of foreign enemies; and second, to induce foreign governments to grant inheritance rights to persons in this country. Although there can be little question as to the worthiness of these goals, there is consider-

the sale of such property. However, there is generally no provision for inheritance of personal property by residents of one country from deceased citizens of the other. Treaty of Friendship, Commerce, and Consular Rights with Germany, Dec. 8, 1923, art. IV, 44 Stat. 2132, 2135 (1923). See Wuson, United States Commercial. Treaties AND INTERNATIONAL LAw 171 (1960); Boyd, Treaties Governing the Succession to Real Property by Aliens, 51 MICH. L. REv, 1001 (1953).

- This latter requirement is discussed in notes 31-36 infra and accompanying text.

- Of the ten reciprocity statutes now in force, seven restrict the inheritance of both real and personal property. See ARIz. REv. STAT. ANN. \$14-212 (c) (1956) (alien eligible for citizenship takes "in same manner" as United States citizen takes in alien's country); CAL. Prob. CODE $\$ 259$ (nonresident alien takes "upon same terms and conditions" as United States citizen provided alien's country extends a reciprocal right); Iowa Code $\$ 567.8$ (1) (Supp. 1962) (identical to California provision); MoNr. REv. CODES ANN. $\$ \S 91-520,-521$ (Supp. 1961) (similar to California provision); NEv. REv. STAT. $\$ \$ 134.230-250$ (1960) (similar to California statute); N.C. GEN. STAT. \$64-3 (1960) (identical to California provision); ORE. REv. STAT. $\$ 111.070$ (1961) (similar to California statute). Two statutes relate only to real property. See CONN. GEN. STAT. REv. \$47-57 (1960) (nonresident Frenchmen given national treatment as long as reciprocal right exists); TEx. REv. Civ. STAT. art. 167 (4) (1959) (nonresident aliens can acquire interest in land if their nation allows Texans to hold land in fee). One statute applies only to personal property. See OKLA. STAT. tit. 60, $\$ 121$ (1951) (nonresident aliens given same rights as to personal property as their nation gives United States citizens).

Statutes requiring that the foreign beneficiary be able freely to receive and use assets make no distinction between personal and real property. See, e.g., N.Y. SURR. Cr. AcT $\$ 269$, quoted infra note 31 . 
able evidence that reciprocity statutes are not well-suited to their accomplishment.

\section{A. Keeping Resources from Unfriendly Nations}

Reciprocity statutes first gained popularity shortly before the United States entered World War II. ${ }^{10}$ The enactment of this legislation was a direct result of the approaching war and was prompted by a desire to keep resources out of the hands of potential enemies. ${ }^{11}$ However, the cases which have been decided under these statutes indicate that the legislative purpose of controlling the flow of assets may not always be carried out. Although claimants residing in nations under Nazi, Fascist, or Communist domination have normally been disinherited for lack of reciprocity, ${ }^{12}$ precedents have evolved under reciprocity statutes whereby such persons may be allowed to inherit property from this country, either (l) where the decedent died at a time when a former government allowed

${ }^{10} \mathrm{An}$ Oregon statute of 1937 placed reciprocity restrictions on the inheritance of personal property by nonresident aliens. Ore. Laws ch. 399 (1937). Montana in 1939 apphed the same conditions to the inheritance of both real and personal property. Mont. Laws ch. 104, $\$ 2$ (1939). California and Nevada followed with similar legisla. tion in 1941. Cal. Stats. ch. 895, § 1 (1941); Nev. Comp. Laws § 9894 (Supp. 1941).

${ }^{21}$ An indication of the arguments made at the time is afforded by a statement of urgency accompanying the California legislation which made the following points: (1) Many foreign countries are now at war. (2) Money and property left to citizens of California by residents of some countries is taken by the governments of those countries for war uses. (3) Money and property left by Californians to residents of such foreign countries is likewise seized by the governments for war purposes. (4) These foreign governments constitute a direct threat to the United States. (5) There. fore it is immediately necessary that property and money of citizens dying in this country not be sent to foreign countries "to be used for purposes of waging a war that eventually may be directed against the Government of the United States." Cal. Stats. ch. 895, $\S(1941)$, reprinted in CAx. PROB. CODE $\$ 259$ (historical note 1956).

The statement of urgency was attached so that the act would become effective im. mediately instead of ninety days after the adjournment of the Legislature. See CAL. Consr. art. IV, $\S 1$.

${ }^{12}$ See, e.g., Estate of Gogabashvele, 16 Cal. Rptr. 77, 195 Cal. App. 2d 503 (1961) (Russia, Aug. 14, 1956); Estate of Nersisian, 155 Cal. App. 2d 561, 318 P.2d 168 (1957) (Russia, 1952); Estate of Leefers, 127 Cal. App. 2d 550, 274 P.2d 239 (1954) (Germany, Jan. 15, 1944); Estate of Arbulich, 248 P.2d 179 (Cal. App. 1952), aff'd, 41 Cal. 2d 86, 257 P.2d 483 (1953) (Yugoslavia, March 21, 1947); Estate of Schluttig, 36 Cal. 2d 416, 224 P.2d 695 (1950) (Germany, April 1945); Estate of Giordano, 85 Cal. App. 2d 588, 193 P 2d 771 (1948) (Italy, Jan. 17, 1945); Estate of Bevilacqua, 31 Cal. 2d 580, 191 P.2d 752 (1948) (Italy, Jan. 28, 1944); In the Matter of the Estate of Stoian, 188 Mont. 384, 357 P.2d 41 (1960) (Romania, Jan. 1, 1949); In the Matter of the Estate of Christoff, 219 Ore. 233, 347 P.2d 57 (1959) (Bulgaria, Oct. 1940, Aug. 1944, Jan. 1945); Clostermann v. Schmidt, 215 Ore. 55, 332 P.2d 1036 (1958) (Germany, April 24, 1945); In the Matter of the Estate of Krachler, 199 Ore. 448, 263 P.2d 769 (1953) (Germany, Dec. 8, 1943). 
inheritance by United States citizens, ${ }^{13}$ (2) where a recognized government-in-exile grants a reciprocal right, ${ }^{14}$ or (3) where the evidence supports a finding that reciprocity exists even under the totalitarian regime. ${ }^{15}$ Thus it appears that if the problem is one of removing the possibility that resources will fall into the hands of actual or potential enemies, reciprocity statutes provide only a partial solution.

\section{B. Encouraging Foreign Nations to Grant Inheritance Rights to United States Citizens}

A second major purpose of reciprocity statutes is to encourage other nations to allow inheritance by United States residents and citizens. ${ }^{16}$ It seems clear that the statutes do provide a theoretical inducement to all nations to allow residents and citizens of this country to inherit estates from within their jurisdictions. However, the theory rings hollow in view of the fact that such statutes as a practical matter are not likely to have any real effect in this regard. In the first place, unless a great number of states act in concert, the impact of their actions will not be greatly felt by foreign governments. In the second place, it is impossible for the states to carry on direct negotiations with other nations. ${ }^{17}$ Moreover, questions of reciprocity usually arise with regard to Communist nations whose

\footnotetext{
${ }^{18}$ Estate of Nepogodin, 134 Cal. App. 2d 161, 285 P.2d 672 (1955) (reciprocity with Manchuria as of 1949); In the Matter of the Estate of Gaspar, 128 Mont. 383, 275 P.2d 656 (1954) (reciprocity with Romania as of 1940); In the Matter of the Estate of Kasendorf, 222 Ore. 463, 353 P.2d 531 (1960) (reciprocity with Estonia as of 1943).

14 Estate of Blak, 65 Cal. App. 2d 232, 150 P.2d 567 (1944) (reciprocity with The Netherlands Government-in-exile as of 1944).

${ }^{16}$ Estate of Kennedy, $106 \mathrm{Cal}$. App. 2d 621, 235 P.2d 837 (1951) (reciprocity found with Romania as of 1949); Estate of Miller, 104 Cal. App. 2d 1, 230 P.2d 667 (1951) (reciprocity found with Germany as of 1942); In the Matter of Estate of Ginn, 136 Mont. 338, 347 P.2d 467 (1959) (reciprocity found with Yugoslavia as of 1955); In the Matter of the Estate of Spoya, 129 Mont. 83, 282 P.2d 452 (1955) (reciprocity found with Yugoslavia as of 1949).

10 The following statement of this policy was made by the Oregon Supreme Court: The purpose of [the reciprocity statute] . . . is clear beyond doubt. . . . It was an inducement to foreign nations to so frame the inheritance laws of their respective countries in a manner which would insure Oregonians the same opportunities to inherit and take personal property abroad that they enjoy in the state of Oregon. Clostermann v. Schmidt, 215 Ore. 55, 68, 332 P.2d 1036, 1042 (1958).

See also In the Matter of the Estate of Krachler, 199 Ore. 448, 457, 263 P.2d 769, 774 (1953).

${ }^{27}$ Even before the time of the Constitution, the states had no power to negotiate with foreign countries. United States v. Curtiss-Wright Export Corp., 299 U.S. 304, 316-17 (1936). The same has been true after that time. See Hauenstein v. Lynham, 100 U.S. 483 (1880).
} 
laws and institutions are such that technical reciprocity would be of no great benefit to residents of their country. ${ }^{18}$ The right of United States citizens to receive money from estates left in foreign nations means little if the laws of that nation discourage or forbid the accumulation of estates from private property. ${ }^{19}$

III

\section{The Case Against Reciprocity}

In addition to their limited effectiveness, reciprocity statutes present positive disadvantages. Two notable ones are: (1) the trouble and expense of proving foreign law, and (2) the possibility of defeating the intent of the decedent.

\section{A. Difficulty of Proving Foreign Law}

The factors militating against a party who wishes to show that a foreign nation grants reciprocal rights of inheritance are considerable. Most reciprocity statutes place the burden of going forward with evidence as well as the burden of persuasion on the party seeking to establish the reciprocal right. ${ }^{20}$ In the absence of competent evidence to the contrary, reciprocity is assumed not to exist. Thus if the foreign claimant is unable to find any law one way or the other, he loses his case.

Even in cases where reciprocity unquestionably exists, the foreign claimant may find it difficult to prove its existence. Under the "fact" doctrine the principal of stare decisis has no effect, for the issue of reciprocity becomes a question of fact to be decided by the jury. ${ }^{21}$ An erroneous finding is not subject to successful appeal unless contrary to the weight of evidence in the record.

${ }^{18}$ See Note, Estates and the "Iron Curtain," Mass. L.Q., May 1950, p. 34.

${ }^{10}$ For an analogous situation in the area of commercial relations, see Pisar, Soviet Confict of Laws in International Commercial Transactions, 70 HARv. L. REv. 593, 624 (1957).

${ }^{20}$ The Montana statute is silent on this point, but the burden has been placed on the nonresident claimant by judicial decision. See In the Matter of Estate of Gaspar, 128 Mont. 388, 387, 275 P.2d 656, 659 (1954).

21 The following illustration was provided by the California Court of Appeal: "The effect of the decision in the Schluttig case . . . is that inheritance of German nationals in Cahfornia estates during the Nazi regime is, as a practical matter, to be determined as each case arises and then is dependent upon which set of experts the trial court may believe." Estate of Miller, 104 Cal. App. 2d 1, 19, 230 P.2d 667, 679 (1951). 
Therefore final outcomes diverge wildly under similar fact situations and precedent becomes meaningless. ${ }^{22}$ Many states have made general provisions for judicial notice of the laws of sister states, but few have extended this doctrine to the laws of foreign countries. ${ }^{23}$ Therefore the foreign claimant may have to present persons qualified as experts in the foreign law, publications which are recognized in the foreign court as evidence of the written foreign law, or authenticated copies of such law. If translation is necessary, it becomes necessary to secure an expert for this purpose.

Even if the claimant is able to introduce evidence of treaties or laws which purport to guarantee a reciprocal right on the part of United States citizens to inherit, the case is not necessarily settled. It may be necessary to prove that the law or treaty was in effect at the time of the decedent's death or that the foreign government actually observes the law on its books. ${ }^{24}$ Where the statute requires that foreign inheritances be receivable in full in this country, ${ }^{25}$ questions of monetary and exchange controls may be brought into the suit. ${ }^{26}$

Fair in theory, but harsh in actual practice, the requirement of reciprocity may thus disinherit more often than intended, simply because the potential inheritance is not sufficiently large to warrant the expenditure necessary to establish that reciprocity does exist.

\footnotetext{
"E.g., compare cases in note 12 supra with cases in note 15 supra.

18 Although several states have provided for judicial notice of the law of foreign countries, 9 WrGmore, Evidence $\$ 2573$ (3d ed. 1940, Supp. 1962), there is but one instance where this practice has affected the operation of reciprocity statutes. Cahfornia in 1957 specifically repealed the "fact" doctrine as embodied in the reciprocity statute and provided for judicial notice as to the applicable foreign law. CAL. Prob. CODE $\$ 259.1$ (Supp. 1962).

North Carolina and Iowa, which otherwise emulated the California legislature, failed to adopt the 1957 refinement. N.C. GEN. STAT. $\$ 64.4$ (1960); IOWA CODE $\$ 567.8(2)$ (Supp. 1962). Ironically enough, North Carolina, which has long provided for judicial notice of foreign law, Pub. Laws of N.C. 1931, ch. 30, specifically incorporated the fact doctrine in its reciprocity statute by adopting verbatim the California statute of 19471 See note 1 supra.

24 See, e.g., Estate of Leefers, 127 Cal. App. 2d 550, 274 P.2d 239 (1954), where it was shown that Nazi Germany did not give effect to its ostensible law which would have allowed inheritance by foreigners.

${ }^{38}$ Only the Oregon statute specifically requires that United States citizens be able to receive inheritances in this country. ORE. REv. STAT. $\$ 111.070$ (1961). It has been suggested that the absence of this feature is a defect in other reciprocity statutes. See Recommendation and Study Relating to the Right of Nonresident Aliens to Inherit, 2 CAL. LAW REVISION Comm'N REPS. \& Recommendations \&. Studies, p. B-1 to B-32 (1959).

Io In the Matter of the Estate of Stoich, 220 Ore. 448, 349 P.2d 255 (1960), rev'd sub nom. Kolovrat v. Oregon, 366 U.S. 187 (1961).
} 
B. The Intent of the Decedent

One of the purposes of statutes affecting inheritance has been to give effect to the expressed or implied intent of the decedent. An important feature of reciprocity statutes is that they operate to defeat the intent of persons leaving estates in this country. Any advantage offered by reciprocity statutes must thus be weighed against the possible disregard of the desires of domestic decedents.

Usually inheritances left to persons ineligible to take because of a reciprocity statute are allowed to pass to residuary legatees, heirs, or next-of-kin. If such other heirs are not found, most statutes provide that the estate shall be disposed of as by escheat. ${ }^{27}$ Moreover, it has been held that where heirs and next-of-kin are excluded by reason of lack of reciprocity, the estate escheats and does not devolve to other relatives of a more remote degree who reside in this country. ${ }^{28}$

The escheat provisions of reciprocity statutes frequently result in defeating the intent of persons dying and leaving property in the United States. ${ }^{28}$ Although any control on the flow of assets to foreign countries must necessarily interfere in some degree with the dispositive intent of decedents, it can well be argued that the absolute and irrevocable measure of escheat is unnecessarily harsh in effecting the desired result. ${ }^{30}$

\section{IV}

\section{TOWARD AN APPROVED APPRoACH}

As the foregoing discussion has indicated, reciprocity statutes do not satisfactorily achieve either of their primary objectives.

\footnotetext{
${ }^{27}$ See note 1 supra.

${ }^{28}$ In the Matter of Estate of Stoian, 138 Mont. 384, 357 P.2d 41 (1960).

${ }^{29}$ See, e.g., Estate of Arbulich, 41 Cal. 2d 86, 257 P.2d 433, cert. denied, 346 U.S. 897 (1953) (decedent left entire estate to brother in Yugoslavia, statute resulted in brother in United States taking entire estate); Estate of Schluttig, 36 Cal. 2d 416, 224 P.2d 695 (1950) (all residuary legatees but one were citizens and residents of Germany or Austria, statute resulted in one legatee in United States taking the entire residue); Estate of Bevilacqua, 31 Cal. 2d 580, 191 P.2d 752 (1948) (widow and children in Italy cut off by statute and first cousin allowed to inherit); Estate of Karban, 118 Cal. App. 2d 240, 257 P.2d 649 (1953) (statute resulted in share of estate going to distant relatives in United States rather than to charity in Czechoslovakia); Estate of Michaud, 53 Cal. App. 2d 835, 128 P.2d 595 (1942) (first cousin in California would take instead of father and two brothers in German-occupied France); Estate of Stoian, 138 Mont. 384, 357 P.2d 41 (1960) (heirs and next of kin in Romania disinherited by statute which caused land to be escheated rather than devolve to United States relatives of more remote degree).

${ }^{30}$ See Chaitkin, The Rights of Residents of Russia and Its Satellites To Share in Estates of American Decedents, 25 So. CAL. L. REv. 297 (1952).
} 
They do not afford a firm guarantee that inheritances from the United States will be cut off from unfriendly countries, nor do they provide an effective means of indirectly enhancing the inheritance rights of domestic citizens. In addition, reciprocity statutes offer positive disadvantages. First, due to the high cost of proving foreign law, that which is reciprocity in theory may be disinheritance in fact. Second, the escheat provisions of existing statutes evidence a particularly low regard for the intent of the decedent.

An alternative means of keeping domestic inheritances from unfriendly nations has been employed by several northeastern states. Either with or without legislative sanction, courts in these states impound assets when it appears that the foreign legatee, distributee or beneficiary would not receive its full beneficial use or control, or when other circumstances make it desirable that payment be withheld. ${ }^{31}$ These courts apply what has been termed the "benefit" rule in that the transfer of property is allowed only if the foreign recipient, and not his government, will receive the full benefit of the inheritance. ${ }^{32}$ Generally the foreigner is not disinherited through escheat, but is merely prevented from removing his inheritance from this country until such time as he can make a successful application to the court.

\footnotetext{
ax Five state legislatures have conferred authority on their courts to determine whether the proceeds of an estate should be released to foreign beneficiaries. See MD. Ann. Code art. 93, §161 (1957); MASs. AnN. LAws ch. 206, §27a (1955); N.J. Stat. ANN. 3A:25-10 (1953); N.Y. SuRR. CT. Act §269; R.I. Gen. Laws \$ 33-13-13 (1956).

The earliest of these statutes, to which the others are similar, was enacted by New York in 1939. It provided as follows:

"Where it shall appear that a legatee, distributee or beneficiary of a trust would not have the benefit or use or control of the money or other property due him, or where other special circumstances make it appear desirable that such payment should be withheld, the decree may direct that such money or other property be paid into the surrogate's court for the benefit of such legatee, . . . who may thereafter appear to be entitled thereto. Such money or other property so paid into court shall be paid out only by the special order of the surrogate or pursuant to the judgment of a court of competent jurisdiction." N.Y. Sess. Laws 1939, ch. $943, \S 269$.

Even in the absence of statutory authority some courts have adopted the practice of impounding distributive shares belonging to persons residing behind the Iron Curtain. Such procedure has been followed in Michigan, Missouri, Nebraska, Pennsylvania, and Vermont. See Chaitkin, The Rights of Residents of Russia and Its Satellites To Share in Estates of American Decedents, 25 So. CAL. L. REv. 297, 313-15 (1952).

One state has adopted this "benefit" approach in addition to the reciprocity requirement. See ORE. Rev. StaT. \$111.070(1) (c) (1957).

"It seems that in terms of fairness to the individual, the "benefit" approach is superior to reciprocity. In one decision the rationale of the "benefit" rule was used by the court although the applicable statute required reciprocity! See In re Nersisian's Estate, I55 Cal. App. 2d 561, 566, 318 P.2d 168, 171 (1957).
} 
The "benefit" rule offers several advantages over reciprocity. Although its articulated purpose is the protection of foreign beneficiaries, courts use the rule to prohibit the sending of bequests of money or property behind the Iron Curtain. ${ }^{33}$ The problem of proving foreign law is minimized by the almost conclusive significance attached by the courts to Treasury Department rulings as to whether there is any assurance that the value of United States checks will be received and duly cashed by individual recipients in the country in question. ${ }^{34}$ The Treasury Department's list is currently composed of almost all the nations of the Communist bloc. ${ }^{35}$ Also, the "benefit" rule is much less harsh than the reciprocity-escheat device in thwarting the intent of the decedent. Instead of permanent disinheritance, the foreign beneficiary faces what may be only the delayed enjoyment of his property. Thus the "benefit" rule meets many of the objections which have been raised to reciprocity statutes. ${ }^{36}$

Perhaps more important than the choice between the "benefit" rule and reciprocity is the need for an entirely new approach to our system of inheritance controls. Existing controls are guilty of failing to take formal account of the real issues at stake. Neither the benefit nor the reciprocity criteria directly confronts the basic question of whether our national welfare will be unduly prejudiced by permitting assets in the form of inheritances to flow to foreign countries. Even should this question be squarely presented, it is hardly appropriate for the answer to be supplied by an individual

\footnotetext{
${ }^{38}$ See, e.g., In re Von Der Heid's Estate, 33 Misc. 2d 812, 227 N.Y.S.2d 807 (Surr. C. 1958); In the Matter of Seigler, 284 App. Div. 436, 132 N.Y.S.2d 392 (1954).

${ }^{34}$ See, e.g., In the Matter of Seigler, 284 App. Div. 496, 192 N.Y.S.2d 392 (1954); In the Matter of Braier, 305 N.Y. 148, 111 N.E.2d 424 (1953); In the Matter of the Estate of Getream, 200 Misc. 543, 107 N.Y.S.2d 225 (1951); In the Matter of the Estate of Yee Yoke Ban, 200 Misc. 499, 107 N.Y.S.2d 221 (1951).

Some courts take judicial notice of conditions and events in the Iron Curtain countries as grounds for withholding payment under the "benefit" theory. See In the Matter of the Estate of Volencki, 35 N.J. Super. 351, 114 A.2d 26 (1955).

${ }^{35}$ The list of countries in which there is no reasonable assurance of payment presently includes Albania, Bulgaria, Communist China, Czechoslovakia, Estonia, Hungary, Latvia, Lithuania, Russia, East Berlin, and East Germany. 31 C.F.R. \$211.3 (Supp. 1962).

${ }_{38}$ The California Law Revision Commission has recommended that the present reciprocity statute be repealed and that a statute reflecting the "benefit" rule be enacted in its place. Recommendation and Study Relating to the Right of Nonresident aliens To Inherit, 2 Cal. Law Revision COMM'N Reps. \& ReCommendations \& Studies, p. B-1 to B-32 (1959).
} 
state. Apart from any consideration of escheat, the state wherein an estate is situated has no more interest in preventing assets from reaching the Communist bloc than does any other state. Since the domestic interest is clearly national in scope, it follows that controls on inheritance across international boundaries should be imposed by the federal government and not by the states.

Federal regulation of inheritance by persons outside the United States does not involve a radical departure from traditional notions of the allocation of federal and state power. Although matters of inheritance are primarily controlled by state law, the federal government has long been active in the field. By means of treaties, ${ }^{37}$ the United States has in some instances provided for inheritance rights which cannot be overridden by state restrictions or inheritance by nonresident aliens. ${ }^{38}$ During wartime, federal controls on inheritance come into play under the Trading With the Enemy Act. ${ }^{30}$ In states employing the "benefit" rule the federal government exercises an indirect control over inheritance in that state courts usually rely on determinations made by the Treasury Department. ${ }^{40}$ Thus in legislating on the subject of inheritance by nonresident aliens, Congress would hardly be invading an area which has heretofore been reserved exclusively to the states. ${ }^{41}$

In summary, the inadequacy of the reciprocity statute and other restrictions on inheritance by nonresident aliens indicates the need for a re-examination of this area of the law. It can be hoped that

s7 See note 7 supra.

so See Kolovrat v. Oregon, 366 U.S. 187 (1961); Clark v. Allen, 331 U.S. 503 (1947).

However, due to their inflexibility, treaties are not likely to provide an adequate solution to the problem of allowing or disallowing inheritance by nonresident aliens. Few treaties presently in existence provide broadly for the inheritance of personal property. See note 7 supra. It would take decades for appropriate treaty provisions to be put into effect. See Meekison, Treaty Provisions for the Inheritance of Personal Property, 44 AM. J. INT'L L. 313 (1950).

8050 U.S.C. APP. $\$ 6$ (1959).

10 See note 35 supra and accompanying text.

"The constitutionality of federal legislation designed to regulate foreign relations and protect domestic interests would seem assured under the recent case of United States v. Oregon, 366 U.S. 643 (1961). In this case it was held that a statute affecting the dispositon of the estates of veterans dying in veterans' hospitals takes precedence over a state statute providing for escheat. Justice Black, speaking for the Court, said:

"The fact that this law pertains to the devolution of property does not render it invalid. Although it is true that this is an area normally left to the States, it is not immune under the Tenth Amendment from laws passed by the Federal Government which are, as is the law here, necessary and proper to the exercise of a delegated power." Id, at 649 . 
Congress will ultimately pass the requisite legislation to establish a uniform means of disallowing inheritance in those instances where it is in the best interest of the national welfare to do so. In the meantime, it can be hoped that state legislatures will replace existing reciprocity statutes with the more enlightened "benefit" rule. 